\title{
Thai Migrant Workers in Agriculture Farms in New Zealand: A Short Case Study
}

\author{
Thongphon Promsaka Na Sakolnakorn ${ }^{1}$, Aree Naipinit ${ }^{2}$, Punya Tepsing ${ }^{3} \&$ Patarapong Kroeksakul $^{4}$ \\ ${ }^{1}$ Institute for Peace Studies, Prince of Songkla University, Hat Yai Campus, Songkhla, Thailand \\ ${ }^{2}$ Faculty of Management Science, Khon Kaen University, Khon Kaen, Thailand \\ ${ }^{3}$ Faculty of Liberal Arts, Prince of Songkla University, Hat Yai Campus, Songkla, Thailand \\ ${ }^{4}$ Faculty of Environmental Culture and Ecotourism, Srinakharinwirot University, Bangkok, Thailand \\ Correspondence: Thongphon Promsaka Na Sakolnakorn, Institute for Peace Studies, Prince of Songkla \\ University, Hat Yai, Songkhla 90112, Thailand. E-mail: thongphon.p@psu.ac.th
}

Received: July 25, 2013 Accepted: September 20, 2013 Online Published: November 29, 2013

doi:10.5539/ass.v9n17p163

URL: http://dx.doi.org/10.5539/ass.v9n17p163

\begin{abstract}
This paper's aim is to study the problems Thai migrant workers face in agricultural farming in New Zealand and to provide guidelines for solving these problems. This study used in-depth interviews conducted between the years 2007 and 2012, with accidental sampling, and the data were analyzed using a content analysis. The study found that the main motivation of Thai workers is to send remittance back home to pay off family debt. Many Thai workers came to work in New Zealand because their relatives motivated them, and the problems they face while there include a limitation of working visas, English language barriers, and an inability to find work. In order to solve these problems the Thai government should train Thai workers both before and after working aboard.
\end{abstract}

Keywords: Thai migrant workers, agriculture, farms, New Zealand

\section{Introduction}

The international migration of labor has benefited both origin and destination countries (Athukorala, 1992; Kaur, 2010). The remittance sent back home by migrant laborers has helped improve living standards, provided education to children, cleared the debt laborers owed to other neighborhoods, and reduced the costs for borrowing in the international capital market (Jones \& Pardthaisong, 1999; Sorensen et al., 2002; Glytsos, 2002; Agbola \& Acupan, 2010). Furthermore, the remittance received from migrants overseas has aided in poverty reduction in the countries of origin (Richard et al., 2005).

International labor migration also depends on factors such communication, transportation, and media (Collins, 1999). Development in communication has enhanced the speed of information transfer, allowing relatives living abroad to send ideas and information to their origin countries. Unemployment is a one factor that leads laborers to migrate away from their home countries (Manning, 2002). The economic crisis was one of the factors that caused unemployment in Southeast Asian nations and these countries have adopted various policies to ease this problem. Some countries like Singapore, Malaysia, Brunei, and Thailand were able to combat the problem, while others are still working to halt the crisis (Kaur, 2009). Therefore, countries like Indonesia, the Philippines, and Bangladesh have adopted policies for sending laborers overseas to ease the unemployment problems at home (Kaur, 2009; Agbola \& Acupan, 2010).

Data from the National News Bureau of Thailand (2013) suggest that the Thai and New Zealand governments have signed an agreement for joint collaboration in many aspects such as, economic activities, education, technology, and agriculture. This agreement will encourage Thai workers to get working visas, as the process is no longer difficult. This paper will present the obstacles Thai migrant workers face when moving to New Zealand, and researchers hope that the results will benefit both the Thai and New Zealand governments in determining the correct policies and practices to support Thai migrant workers. This study could also serve as a case study for many other countries similarly to Thailand. 


\section{Objective}

To study problems of Thai migrant workers in agriculture farm in New Zealand

\section{Methodology}

In this paper researchers have used fieldwork surveys and in-depth interviews conducted with Thai workers using accidental sampling. We interviewed two Thai workers in Christchurch in 2007, five Thai workers in Nelson in 2012, four Thai workers in Auckland in 2011 and 2012, two Thai workers in Hawkes Bay in 2012, seven Thai workers in Wellington in 2009, 2010, and 2011, and three Thai workers in Queenstown in 2011 and 2012, analyzing the data using a content analysis. The in-depth interviews consisted of four main questions: what is your motivation to work in New Zealand? Why did you come to work in New Zealand? What are the obstacles Thai migrant workers face? and what support was given by the Thai government?

\section{Results}

Researchers interviewed two headmen Thai workers (one in Nelson and one in Napier; these Thais were called "Boss"), asking them "why would you like to employ Thai workers and bring them to New Zealand?" The answers they gave were that Thai workers were honest and hardworking, they possessed the skills to do the job, and they readily followed orders. It should also be noted that most Thai workers come from rural areas in the northeast region of Thailand. Jones and Pardthaisong (1999) suggested that the impact of overseas labor migration in rural Thailand is overall very positive. When Thais work overseas, they earn a considerable amount of money to send back home, which supports their family's activities in their villages. Their families thus have more money to invest in farming.

From the study, we found that the main motivation for working abroad is that Thai workers wanted to receive more income and send remittance back home.Manypeople primarily migrate to destination countries because those countries provide higher wages than their countries of origin does, allowing them to send more money to their families and help to improve living standards and clear debts. By interviewing a Thai migrant worker at Nelson City in South island in 2012, this study found that:

"My family works in farming, and if it is not agriculture season, then I don't have a job; however, even if I were to get a job it would below income and not enough for my family to live. That is the reason that I came to work on a Kiwi fruit farm in New Zealand"

From interviews, it becomes evident that one of the main motivations of Thai laborers to work overseas is "to gain more income." This is similar to what was found in a study done by Baka and Laeheem (2006), who suggested that economic issues are influential in guiding people's decisions to migrate. Another motivation for Thai workers coming to work in New Zealand was that their relatives were persuading them to do so, telling them about the positive aspects of working in New Zealand. In addition, many employers in New Zealand help Thai migrant workers by guaranteeing working visas and paying their airfare to New Zealand, with no extra payments to overseas work agencies (in the past Thai workers had to pay more than 3,000 USD to overseas work agencies). However, the main problem is that Thai workers can receive only one year work visas, and they are difficult to extend. Also due to the nature of the work, they can only work during agricultural season; therefore, they work for six months and then return home to Thailand, resting for 4-6 months before returning to work again. This is problematic as workers are unable to break even because the approximately 1,000 USD they earn per month must be spent on monthly living costs (rent, food, etc.) airfare, etc. The six months they work does not allow them to save money for their family; it only covers their cost of living in New Zealand. Concerning visa issues, one Thai worker interviewed said this:

"My visa expired last month, now I cannot work, because I am waiting to extend my work visa a second year. I do not know when I will gain a visa; if I don't receive a second year visa, I will have to go back home next month, because staying and waiting here is very costly."

New Zealand's visa issues are a big concern to Thai workers. Promsaka Na Sakolnakorn (2012) study found that it is very difficult for Thai workers to obtain work visas, concluding that the Thai government should support Thai people wanting to work in New Zealand due to this difficulty. In addition, the most significant problem for Thai workers returning home is that they cannot find jobs that provide the same high income that they received in New Zealand.

The language barrier is another obstacle Thai workers face in New Zealand. When workers are unable to speak English, they must communicate with their employers through a Thai headman or through other Thai workers who speak and understand English. However, even this becomes a problem as one Thai worker explains: 
"Because I cannot speak English and cannot communicate to my employers, I have found that some headmen will take advantage me and other workers who don't speak English. However, this does not seem to be a problem if the headman is our relative",

Another problem associated with English language issue is that most Thai workers will sign their contracts without reading them because they do not understand English. Our research has shown that in some cases workers assume the employer will pay for housing, but in reality, these workers have to pay for their own housing, failing to understand the conditions of the contract. Our study shows that it is necessary for Thai workers to study English before going to work in New Zealand. Workers also think that the Department of Employment should provide free training to migrant workers who would like to work overseas, one to three months before they go to work in New Zealand. This is an important issue because it would enable workers to communicate with employers and also qualify them for even better jobs. In addition, the Thai government should also help develop workers' skills with training courses through collaboration with the private sector. Furthermore, it should track the skills Thai migrant workers gained after working abroad (Intarak, Phuangrod \& Wongmontha, 2006).

Despite the problems associated with labor migration, there are also many merits. Remittance is one of them. Migrants working abroad earn their living working overseas and at the same time manage to send home a good amount of remittance. The remittances their families receive have proved beneficial in many ways, such as in educating children, constructing houses, purchasing necessary goods, and clearing debts. Remittances have also helped in eradicate poverty to a certain extent, although many researchers have argued this point. In addition, remittances have helped in the economic development of these nations, leading many countries with manpower to send workers abroad to earn cash to send back to their respective countries.

Finally, in this paper we have found that the most significant problem for workers returning home is that they cannot find jobs that provide the same high income that they received in New Zealand. In addition, after Thai workers return home, they need jobs that offer comparable wages to those they received in New Zealand. Despite being skilled workers who have received training and gained experience in New Zealand, when they return home they still receive income comparable to the income of those who have never been abroad. So, the government should train workers who return from overseas to work at home in small businesses and community enterprises, together with domestic farm workers so that everyone might benefit.

\section{Conclusion}

Thai migrant workers can therefore improve Thailand's income. Thai workers in New Zealand receive approximately 1,000 to 1,500 USD per month, yet if they worked in Thailand, they would receive no more than 300-500 USD per month. Though the migrant workers endure difficult work and homesickness, they earn enough money to support their families, they are able to provide for their children's school and university tuition fees, and they can repair their houses and buy vehicles, televisions, and other material goods. The biggest problem Thai migrant workers in New Zealand face is the limited number work visas issued. Because Thai workers only receive one-year work visas, they are unable to earn enough money for break even. In order to solve this issue, the Thai government should negotiate with the New Zealand government extended work visas, which last more than one year. Also, according to the study conducted by Promsaka Na Sakolnakorn (2012), while many other migrant workers from China, Vietnam, and India are working in New Zealand, Thai workers seem to find it more difficult to obtain work visas.

In addition, a migrant worker's ability to live sustainably after he or she returns is very important. To support Thai workers after they return home, the government should train workers who return from overseas to work at home in small businesses and manufacturing. They could work as subcontractors to small, medium, and large enterprises, receiving income per piece while still working on their farms. This strategy could help them earn a higher income than they would by working on their own farms or in agricultural production alone. A study by Promsaka Na Sakolnakorn (2011) has suggested that people who work as subcontractors can increase their income and thereby raise their quality of life. These workers will have more money to repair their homes and buy products such as televisions and vehicles. Subcontractor work can also help them earn more money while staying closer to home with their families. This will therefore improve their families' lives as well.

\section{References}

Agbola, F. W., \& Acupan, A. B. (2010). An empirical analysis of international labor migration in the Philippines. Economic Systems, 34(4), 386-396. http://dx.doi.org/10.1016/j.ecosys.2010.03.002

Athukorala, P. C. (1992). The use of migrant remittance in development: Lessons from the Asian experience. 
Journal of International Development, 4(5), 511-529. http://dx.doi.org/10.1002/jid.3380040504

Baka, D., \& Laeheem, K. (2006). The deportation of Thai laborers by the Malaysian government: Causes and impacts. Songklanakarin Journal of Social Sciences and Humanities, 12(2), 177-188.

Collins, W. J. (1999). Labour mobility, market integration, and wage convergence in late $19^{\text {th }}$-century India. Explorations in Economic History, 36(3), 246-277. http://dx.doi.org/10.1006/exeh.1999.0718

Glytsos, N. P. (2002). The role of migrant remittances in development: Evidence from Mediterranean countries. International Migration, 40(1), 5-26. http://dx.doi.org/10.1111/1468-2435.00183

Intarak, C., Phuangrod, S., \& Wongmontha, O. (2006). Public and private cooperation in labor development of southern provinces for AFTA development. Songklanakarin Journal of Social Sciences and Humanities, 12(4), 561-576.

Jones, H., \& Pardthaisong, T. (1999). The impact of overseas labour migration on rural Thailand: Regional, community and individual dimensions. Journal of Rural Studies, 15(1), 35-47. http://dx.doi.org/10.1016/S0743-0167(98)00052-7

Kaur, A. (2009). Labour crossing in Southeast Asia: Linking historical and contemporary labour. New Zealand Journal of Asian Studies, 11(1), 276-303.

Kaur, A. (2010). Labour migration trends and policy challenges in Southeast Asia. Policy and Society, 29(4), 385-397. http://dx.doi.org/10.1016/j.polsoc.2010.09.001

Manning, C. (2002). Structural change, economic crisis and international labour migration in East Asia. The World Economy, 25(4), 359-385. http://dx.doi.org/10.1111/1467-9701.00437

National News Bureau of Thailand. (2013). Economic collaboration between Thailand and New Zealand. Retrieved July 17, 2013, from http://thainews.prd.go.th/centerweb/News/NewsDetail?NT01_NewsID=WNPOL5603220020005

Richard, H., Adams, J. R., \& John, P. (2005). Do international migration and remittances reduce poverty in $\begin{array}{llll}\text { developing } \quad \text { countries? } & \text { World }\end{array}$ http://dx.doi.org/10.1016/j.worlddev.2005.05.004

Sakolnakorn, T. P. N. (2011). Economic and social development by management using outsourcing and subcontracting strategy. The International Journal of Environmental, Cultural, Economic and Social Sustainability, 7(5), 273-286.

Sakolnakorn, T. P. N. (2012). A Study of the Management of Thai Food Shops in Auckland, New Zealand. Journal of Business Case Studies, 8(2), 1-4.

Sorensen, N. N., Hear, N. V., \& Pedersen, P. E. (2002). The migration-development nexus evidence and policy options. International Migration, Special Issue, 40(5), 260-287.

\section{Copyrights}

Copyright for this article is retained by the author(s), with first publication rights granted to the journal.

This is an open-access article distributed under the terms and conditions of the Creative Commons Attribution license (http://creativecommons.org/licenses/by/3.0/). 